\title{
New Approaches to Islamic Law and the DOCUMENTARY RECORD BEFORE I 500
}

\author{
Marina Rustow \\ Princeton University
}

\begin{abstract}
Marina Rustow notes how prevalent scholarly attention is to long-form texts of Islamic law - attention that she argues, comes at the expense of studying Islamic legal documents in a sufficient manner. Study of the documents is an indispensable enterprise if we are to fully understand "how law worked in practice." In view of what we know to have been "heaps" of documents produced by Muslim judges and notaries, Rustow underscores how particularly noticeable a disjuncture there is between those documents and the long-form texts. Moreover, scholars often skip over and thus fail to avail themselves of the utility of documents in adding texture to social and legal history. She cautions social historians against "pseudo-knowledge," that is, the temptation to overlook complex factors, usually embedded in legal documents, that render our otherwise tame scholarly perception of the past truer but more "unruly." In the end, her invitation to join her in the study of documents and thereby improve the state of Islamic legal history is terse and timely: "Please go find yourself some documents."
\end{abstract}




\begin{abstract}
lthough thousands of Arabic and Persian legal documents survived from the medieval Islamicate world, they still appear only rarely in discussions of Islamic law. That's starting to change, but if we want a well-rounded picture of how law worked in practice, it needs to change faster. Those of us who specialize in documents aren't interested in hiding them from others. There are too many texts in need of editing, and we're only too happy to help others locate and decipher them. But, as the joke about shrinks and lightbulbs goes, first specialists in long-form legal works have to be convinced of the value and potential of documents as a source for legal history.
\end{abstract}

\title{
A DiVISION OF SCHOLARLY LABOR
}

I don't work on Arabic legal documents. I study other documents: trade letters, accounts, personal letters and legal and administrative documents in Hebrew script from the Cairo Geniza, sometimes from elsewhere, and Arabic state documents, a category that includes decrees and rescripts from caliphs, sultans and viziers, bureaucratic reports, archival registers, fiscal accounts and receipts, and petitions. The project has led me into thorny questions about the relationship of documents to institutions. They're not the same questions the legal documents raise, but when I read scholarship on law and documents, I recognize my own problems.

Islamic studies has established traditions of specializing in long-form texts, whereas I worry that if people like me don't study documents and teach others how to do so, no one will bother. It's a peculiarity of medieval Middle East studies that even the historians among us focus disproportionately on books rather than documents. Just as the medieval Islamicate world attached social prestige to literacy, books and textual transmission, so, too, does our field attach intellectual prestige to the consumption of long-form texts. We've internalized the values of those we study, but there have been only sporadic attempts to 
explain them. ${ }^{1}$

The long-form/documentary division of labor is as old as university-based Islamic studies. There's nothing inherently wrong with it: Islamic legal writings cover more than a thousand years and a huge swath of the globe. Islamic law is a complex and ramified subject, including positive law, scholastic debate among the schools, sources of law and jurisprudence, theological underpinnings of law, polemics, and the roles of $q \bar{a} d \bar{l} \mathrm{~s}, m u f t \bar{\imath} \mathrm{s}$ and other legal experts.

The documentary side also requires specialists. The surviving legal documents include contracts of sale, lease, loan, guarantee (damān), and marriage, receipts and quittances, deeds of property endowment and manumission of slaves, powers of attorney, court records (mahädir), court registers and piles of as yet unmapped and undefined document types. To understand them, it helps to read as many documents as possible. But the number of published legal documents, while it is increasing, is not enormous. Studying documents therefore inevitably means contact with manuscripts and competence at documentary paleography.

Then there's the problem of where to find documents. The caches we know about have disparate and sometimes vague origins, and some are dispersed across multiple libraries. But many if not all of them contain Arabic notarial documents and Islamic court records. From Egypt, there are the genizot of the Ben Ezra and Dār Simḥa synagogues in Cairo, ${ }^{2}$ the archive of the Jewish community of Cairo, ${ }^{3}$ and possibly other archives

$1 \quad$ E.g., Michael Chamberlain, Knowledge and Social Practice in Medieval Damascus, 1190-1350(Cambridge: Cambridge University Press, 1994); Elias Muhanna, The World in a Book: Al-Nuwayri and the Islamic Encyclopedic Tradition (Princeton: Princteon University Press, 2017); Luke Yarbrough, Friends of the Emir: Non-Muslim State Officials in Premodern Islamic Thought(Cambridge: Cambridge University Press, 2019); and Beatrice Gruendler, The Rise of the Arabic Book (Cambridge, MA: Harvard University Press, 2020).

2 For a new, practical guide to the documentary geniza, its historiography and its potential, see Jessica Goldberg and Eve Krakowski, eds., "Documentary Geniza Research in the Twentieth Century," a triple issue of Jewish History 32, 2-4 (2019).

3 D. S. Richards, "Arabic Documents from the Karaite Community in Cairo,” Journal of the Economic and Social History of the Orient 15 (1972): 105-62, 
as well. ${ }^{4}$ There are tens of thousands of Arabic papyri from myriad archeological caches, ${ }^{5}$ the largest collection of them in Vienna and currently being catalogued and digitized. ${ }^{6}$ There are digitized collections at the University of Utah (the collection of A. S. Atiya), ${ }^{7}$ the University of Cambridge, ${ }^{8}$ and Princeton University ${ }^{9}$ (the latter two both from the collection of George Anastas Michaelides). From Syria, there is a cache of more than two hundred thousand texts from the Umayyad mosque in Damascus, now in Istanbul. ${ }^{10}$ In Jerusalem, there is a substantial cache of legal documents from the al-Aqșā mosque, ${ }^{11}$ and Arabic

and on their current location, Rustow, Lost Archive: Traces of a Caliphate in a Cairo Synagogue (Princeton: Princeton University Press, 2020), 495-96 nn. 7-8.

4 The Coptic Patriarchate Archive in Cairo and the Greek Orthodox Patriarchate Archive of Alexandria are likely to be relevant to Islamic legal studies; I don't know whether they hold pre-Ottoman material. Both are mentioned in Tamer el-Leithy, "Living Documents, Dying Archives: Towards a Historical Anthropology of Medieval Arabic Archives," al-Qanțara 32 (2011): 389-434.

5 For papyrus documents, see Petra M. Sijpesteijn, "Arabic Papyri and Islamic Egypt," in The Oxford Handbook of Papyrology, ed. Roger S. Bagnall (Oxford: Oxford University Press, 2009), 452-72. For Arabic documents more broadly, see The (Cumulative) Arabic Papyrology Bibliography of Editions and Research (henceforth APB), especially the landmark publications of legal documents by Grohmann, Khan, and Diem, and the Arabic Papyrology Database. For the Mamluk period, see Frédéric Bauden, "Mamluk Era Documentary Studies: The State of the Art," Mamlūk Studies Review 9 (2005): 15-60. For a recently unearthed and published personal archive from the Fatimid period, see Christian Gaubert and Jean-Michel Mouton, Hommes et villages du Fayyoum dans la documentation papyrologique arabe (Xe-Xie siècles) (Geneva: Droz, 2014). an National Library.

6 There are images of 1,124 Arabic papyri on the website of the Austri-

7 https://collections.lib.utah.edu/search?\&facet_setname_s=uum_appp.

8 https://cudl.lib.cam.ac.uk/collections/michaelides/1.

9 https://dpul.princeton.edu/islamicmss/catalog/hm50tr79b.

10 At the Turkish and Islamic Arts Museum. See most recently Arianna D’Ottone Rambach, Konrad Hirschler and Ronny Vollandt, eds., The Damascus Fragments: Towards a History of the Qubbat al-khazna Corpus of Manuscripts and Documents (Beirut: Ergon Verlag, 2020), https://doi.org/10.5771/9783956507564.

11 Linda S. Northrup and Amal A. Abul-Hajj, "A Collection of Medieval Arabic Documents in the Islamic Museum at the Ḥaram al-Šarîf," Arabica 25 (1978): 282-91; Donald P. Little, A Catalogue of the Islamic Documents from al-Haram ašŠarīf in Jerusalem (Beirut-Wiesbaden: Franz Steiner Verlag, 1984); Huda Lutfi, AlQuds al Mamlükiyya: A History of Mamluk Jerusalem Based on the Haram Documents (Berlin: Klaus Schwarz Verlag, 1985); Christian Müller, Der Kadi und seine Zeugen: Studie der mamlukischen Haram-Dokumente aus Jerusalem (Wiesbaden: Harrassowitz, 2013), and see below. 
papyri have been excavated elsewhere in Palestine, ${ }^{12}$ as well as in Iraq..$^{13}$ There are also scattered caches from Central Asia; among those that have surfaced in Afghanistan since the 1990s there are many legal documents. ${ }^{14}$ Some caches are available online as high-resolution digital images; others are long overdue for digitization; still others have been the objects of extensive digital database projects. ${ }^{15}$

The Cairo Geniza is worth singling out in this context as a source of Arabic-script legal documents, because Islamic legal scholarship has rarely acknowledged its bounties, with the important exceptions of Geoffrey Khan's landmark publication of Arabic geniza documents and some promising work-in-progress. ${ }^{16}$ The myth nonetheless staggers on that the geniza pre-

12 For the Arabic papyri from Nessana and Khirbet el-Mird, see the APB.

13 Five texts from the third/ninth century were excavated at Samarra in the 1920s. See Ernst Herzfeld, Geschichte der Stadt Samarra (Hamburg: Verlag von Eckardt and Messtorff, 1948).

14 Geoffrey Khan, Arabic Documents from Early Islamic Khurasan (London: The Nour Foundation, 2007); Ofir Haim, “An Early Judeo-Persian Letter Sent from Ghazna to Bāmiyān," Bulletin of the Asia Institute, n.s., 26 (2012): 103-19; Ofir Haim, "Legal Documents and Personal Letters in Early Judaeo-Persian and Early New Persian from Islamic Khurāsān (5th/11th Cent.)" (M.A. thesis, Hebrew University of Jerusalem, 2014); Ofir Haim, "Acknowledgment Deeds (iqrārs) in Early New Persian from the Area of Bāmiyān (395-430 AH/1005-1039 CE)," Journal of the Royal Asiatic Society 29 (2019); and Ofir Haim, "What is the 'Afghan Genizah'? A Short Guide to the Collection of the Afghan Manuscripts in the National Library of Israel, with the Edition of Two Documents," Afghanistan 2 (2019). The only collection of so-called "Afghan Genizah" texts that is now publicly available is owned by the National Library of Israel; all have been digitized. The Invisible East project at Oxford is now developing a database of these documents and others from Central Asia. For a much earlier publication of a Persian legal document from Bamiyan, see Gianroberto Scarcia, "An Edition of the Persian Legal Document from Bāmiyān," East and West 16 (1966): 290-95.

15 The oldest of these, to the best of my knowledge, is the Princeton Geniza Project (PGP), founded in 1985 by Mark R. Cohen and A. L. Udovitch. (I became its director in 2015.) The Arabic Papyrology Database is indispensable. A more recent database is Islamic Law Materialized, directed by Christian Müller, but only a small part of it is open access. (I'm acutely aware of the temptation to restrict access to a database for fear that the some of the data it contains is messy, raw, misleading or too important to risk releasing like drops into a vast ocean. But given the dearth of editions available and how scattered they are, the temptation should be resisted.)

16 Geoffrey Khan, Arabic Legal and Administrative Documents from the Cambridge Genizah Collections (Cambridge, 1993; henceforth ALAD) contains roughly sixty-nine of legal documents (doc. 53 may be a state document; doc. 95 is a legal document). Wissem Gueddich of the EPHE is currently writing a dissertation on 
served only Hebrew-script texts. Even those who know Khan's corpus may mistakenly believe that he finished the job and there are no legal documents left to publish, but the opposite is true: Khan published a selection only from the Cambridge University Library, which houses half the geniza; the other half is dispersed across at least five dozen collections; and there are still scores of unpublished legal documents in Cambridge. ${ }^{17}$

Now that you've found some documents to work on, be warned that they can be challenging to decipher. It's admittedly easier to read the formulaic texts of legal deeds than the free text of letters. But coaxing meaning from formulaic texts requires its own strategies, starting with unpeeling their rigid-looking exterior. The fungible parts of the text - which historians usually consume first - are like the creamy center of the sandwich cookie: you're cheating if you eat it first and leave the rest on the kitchen counter for your parents to clean up. Formulae, too, tell stories: they have histories that reach back in time, often across languages and scribal traditions; they index contact across empires, religions and regions. The institutional settings in which scribes worked are often not visible to us, but sometimes we can reconstruct them from of documents' script styles, layout and wording. ${ }^{18}$ But when you reach the fungible text, you will face a different problem of compression: in a very small space, you'll find legal dramas, family conflicts, financial dilemmas, elaborate negotiations, creative solutions and a panoply of human stratagem and manipulation. It takes creativity to reimagine the real-time, cinematic version of events (as I often press my students to do); it's nearly always worth the effort.

bills of sale for real estate and slaves; and Craig Perry draws on some Arabic-script legal documents in his book-in-progress on medieval slavery.

17 My team at Princeton has identified some of these, and they will appear in the PGP over the next few years. For a practical guide to the documentary Geniza, see Oded Zinger, "Finding a Fragment in a Pile of Geniza: A Practical Guide to Collections, Editions, and Resources," in Documentary Geniza Research in the Twentieth Century, ed. Goldberg and Krakowski, Jewish History 32 (2019): 279-309.

18 Eve Krakowski and Marina Rustow, "Formula as Content: Medieval Jewish Institutions, the Cairo Geniza, and the New Diplomatics," Jewish Social Studies 20 (2014): 111-46. 
Given the differing technical challenges of long-form and documentary texts, it's perhaps understandable that we've divided the labor. But it's also time to make the shop floor openplan. Doing so is all the more pressing if we want to understand how substantive law on the books related to the documents drawn up in courts, the documents being how most people encountered the legal system.

\section{DOCUMENTS IN ISLAMIC LAW, DOCUMENTS IN ISLAMIC LEGAL STUDIES}

How law books and real-world documents relate is, I would imagine, a complicated question in many legal systems. But it's complicated in Islamic law in ways particular to it, because in addition to the question of what documents have to tell us about law, there is also the question of the status of documents in law. One might be forgiven for thinking that we have to understand the function of documents in Islamic legal proceedings before we can learn about legal practice by using documents as historical sources. But logical though it may seem to any historian to ask how an archive came into being before mining it for information, asking jurists to tell us about the status of documents is not going to get us very far unless we're also asking the documents themselves what their function and status was.

The problem begins with the jurists themselves, who granted certain types of documents probative value under defined conditions, as when corroborated by witnesses or authenticated in other ways. ${ }^{19}$ Someone who doesn't study Islamic law might

19 The literature on this subject is by now extensive. Landmarks include Emile Tyan, Le notariat et le régime de la preuve par écrit dans la pratique du droit musulman (Harissa: Faculté de droit de Beyrouth, 1959); Jeanette Wakin, The Function of Documents in Islamic Law: The Chapters on Sales from Tahāwì's Kitāb alShurūt al-Kabīr (Albany: SUNY Press, 1972); Monika Gronke, "La rédaction des actes privés dans le monde musulman médiéval: Théorie et pratique," Studia Islamica 59 (1984): 159-74; Baber Johansen, "Formes de langage et fonctions publiques: Stéréotypes, témoins et offices dans la preuve par l'écrit en droit musulman," Arabica 44 (1997): 333-76; Brinkley M. Messick, The Calligraphic State: Textual Domination and History in a Muslim Society (Berkeley: University of California Press, 1993); 
regard this point as merely technical or procedural. But behind it lurk epistemological and historical problems to do with oral and written transmission, and these problems extend well beyond law to all the other Islamicate branches of knowledge.

Every branch of knowledge held information to be authentic, at least in theory, when transmitted by an unbroken chain of transmitters who were reliable in technically defined ways. This was the tradition's way of guaranteeing quality control, just as people do in our line of work with peer review and reputable publishing houses. Michael Cook notes that by the third/ninth century, the oral transmission of hadi $t h$ "operated in a context permeated by the use of writing." ${ }^{20}$ Hossein Modarressi explains more concretely that the early transmitters of hadith kept notebooks, called by technical Arabic terms including juz' (quire), nuskha (exemplar), aṣl (source), șaḥ̄$f a$ (which I would venture to translate in this context as daybook or register), and kitāb(written document); these terms "conveyed the sense of a personal notebook or material received through oral transmission, perhaps originally simply a jotter," and by the third Islamic century, there were hundreds of them. ${ }^{21}$ Gregor Schoeler has explained the system as a holdover of the Hellenistic habit of transmitting official texts orally and using writing

Messick, "Evidence: From Memory to Archive," Islamic Law and Society 9 (2002): 231-70; and Christian Müller, whose work is discussed below. For recent overviews, as well as important early modern and modern examples of written documentation constituting legal proof, see Guy Burak, "Documents," in The [Oxford] Encyclopedia of Islam and Law <http://www.oxfordislamicstudies.com/article/opr/t349/e0121>; and Jessica Marglin, "Written and Oral in Islamic Law: Documentary Evidence and Non- Muslims in Moroccan Shari a Courts," Comparative Studies in Society and History 59 (2017): 884-911 (885-92, with a focus on the madhähib's approach to documents and the hitherto neglected Mālikī school); and Messick, Sharī a Scripts: A Historical Anthropology (New York: Columbia University Press, 2018). Intisar Rabb points out that in fact documents could have probative value without the testimony of two witnesses: Intisar A. Rabb, "The Curious Case of Bughaybigha, 661-883: Land and Leadership in Early Islamic Societies," in Justice and Leadership in Early Islamic Courts, eds. Intisar A. Rabb and Abigail Krasner Balbale (Cambridge, MA: Harvard University Press, 2017), 23-36.

20 Michael Cook, "The Opponents of the Writing of Tradition in Early Islam," Arabica 44 (1997): 437-530.

21 Hossein Modarressi, Tradition and Survival: A Bibliographical Survey of early Shī ite Literature(Oxford: Oneworld, 2003), xiv, with earlier scholarship and important methodological points on $\mathrm{xv}$. 
only as a mnemonic or as private notes ${ }^{22}$ like some traditions of musical notation today. ${ }^{23}$

As to how the distinction between oral and written transmission of information - and, in practice, their intertwinement - played out in Islamic law and the scholarship on it,Émile Tyan, Joseph Schacht and Jeanette Wakin each wrote about what he or she saw as the contradiction between early Muslim jurists' "refusal to recognize written documents," as Wakin categorically put it in her edition of part of al-Ṭahawī's Great Compendium of Formulae (al-Jāmi al-kabīr fì al-shurūt ), and the fact that judges and notaries nonetheless produced heaps of them. ${ }^{24} \mathrm{Al}-$ though "documents were not accepted as proof in the technical sense," Wakin explained, they were "vital ... to the functioning of law in practice" because they "acted as a firm record and even proof of the transaction." 25 Eventually, these scholars argued, the jurists paid attention to the tension between theory and practice, merging them in two distinct ways: by requiring the use of witnesses to authenticate the contents of documents orally, and by developing a repertoire of standard document texts via a new genre of legal literature, 'ilm al-shurūt, literally, the science of documents, but in practice, formularies. At the intersection between theory and practice were notaries - the scribes who

22 Gregor Schoeler, Écrire et transmettre dans les débuts de l'islam (Paris: PUF, 2002).

23 For parallels in late antique and medieval rabbinic Jewish practice, see Judith Olszowy-Schlanger, "Cheap Books in Medieval Egypt: Rotuli from the Cairo Geniza," in Intellectual History of the Islamicate World 4 (2016): 82-101; Olszowy-Schlanger, "Reading in the Provinces: A Midrash on Rotulus from Damira, Its Materiality, Scribe, and Date," in Continuous Page: Scrolls and Scrolling from Papyrus to Hypertext, ed. Jack Hartnell (London: Courtauld Books, 2019); Anna Busa, "The Rotuli Corpus of the Medieval Midrash Pirqa de-Rabbenu ha-Qadosh," Fragment of the Month, Genizah Research Unit, Cambridge University Library (July 2017); David Stern, The Jewish Bible: A Material History (Seattle: University of Washington Press, 2017), 70-78; and Rustow, Lost Archive, chap. 14.

24 Émile Tyan, Le notariat et le régime de la preuve par écrit (Beirut, 1948); Wakin, Function of Documents, 8; cf. Joseph Schacht, An Introduction to Islamic Law (Oxford: Oxford University Press, 1964), 9: "The use of written documents is well attested for the pre-Islamic period and for the time of Muhammad, and it continued without interruption into Islamic law, although its theory took no notice of it."

25 Wakin, Function of Documents, 27, 41. 
wrote the documents.

Schacht, Wakin's doctoral advisor, had also edited chapters of the same work of al-Tahāwī, one on loans and deposits, the other on preemption (co-owners' right of first refusal to buy out their partners' shares). ${ }^{26}$ Schacht held that formularies were "one of the most important sources of legal practice in Islam." 27 By this he meant not that formularies were historical sources for reconstructing legal practice - formularies, after all, are prescriptive works, not evidence of practice - but rather that formularies served as models for notarial practice. Many after Schacht have understood him as saying that what the jurists said had nothing to do with what happened in courts of law. But he didn't consistently take such an extreme view; Schacht's own writings on the topic are more equivocal. ${ }^{28}$

Nonetheless, Schacht's emphasis on shurūt models is, from my point of view, odd: if he wanted to reconstruct legal practice, he could just as easily have cited original documents, as Wakin later would. Why didn't he? Did he shy away from documents? In his 1948 review of Tyan's study of Muslim judicial procedure, Schacht commented on the "professional illegibility"

26 Joseph Schacht, Kitāb adhkār al-ḥuqūq wa l-ruhūn min al-Djāmi ' alkabìr fi l-shurūt(Heidelberg, 1927) and Joseph Schacht, Kitāb al-shuf'a min al-Djāmi ' al-kabìr fi l-shurūt (Heidelberg, 1930).

27 Schacht in his review of Tyan, Notariat, Orientalia 17 (1948): 519 22, esp. 521 .

28 From the same side of the fourth/tenth century watershed but with a stack of fiqh books to hand, Baber Johansen argued that the jurists had never been as categorical about the primacy of oral testimony as Schacht had supposed (or as Johansen thinks Schacht had supposed; what Schacht himself thought is not as clear). Johansen's revision to Schacht and Wakin consisted in his moving beyond the early period. Like them, he mustered Hanafĩ discussions of the problem, but unlike them, he discussed the period after al-Ṭahawī. Baber Johansen, "Formes de langage et functions publiques: stéréotypes, témoins, et offices dans la preuve par l'écrit en droit musulman," Arabica 44 (1997): 333-76. The passage he cites from Schacht on p. 333 (from Introduction to Islamic Law, 193) doesn't quite say what Johansen says it does. For a recent, forceful refutation of the "orientalist" view that the jurists ignored reality, see Mohammed Fadel, "State and Sharia," in The Ashgate Research Companion to Islamic Law, ed. Rudolph Peters and Peri Bearman (Routledge, 2014), 93-107; for a helpful review of the positions in the debate, see Marion Katz, "Age of Development and Continuity, 12th-15th Centuries CE," The Oxford Handbook of Islamic Law, eds. Anver M. Emon and Rumee Ahmed (Oxford: Oxford University Press, 2018), 45051. 
of the notaries, which "strikes the eye when looking at the extensive collection of documents on paper in the Egyptian Library in Cairo," where he had lived between 1935 and 1939. Schacht characterized the paper documents as "a collection which, incidentally, deserves no less careful a study than the papyri" (that they're on paper dates them post-290/900). ${ }^{29}$ But, unless I've missed it, Schacht never incorporated them into his scholarship: Schacht didn't use documents as a reality-check in the face of the jurists' theoretical law, but rather used shurūt books as evidence of how their jurist authors "sought to make their formularies safe from the possible effects of differences of doctrine." ${ }^{30}$ Schacht was, in other words, interested in documents not for their own sake, but as an index of the jurists' influence on court practice. He believed that there was a continuum between the jurists and the courts; but he ignored the evidence of real documents which, it turns out, would have supported his argument.

It was Wakin who took up that challenge, at least partly. Before I explain how, I feel compelled to say that Wakin was the inspiring teacher who introduced me to Islamic law in the three years before her untimely death in 1998. It was only a decade later that I fell in love with Arabic-script documents and diplomatics, and I never discusssed them with her. It has, then, amazed me to reread Wakin over the course of writing this piece, knowing what I now know. She put the few published papyri at her disposal to good use - not just those in Arabic, but in Aramaic, Demotic and Coptic, with glances at Latin diplomatics - and they helped her to resolve the problem, or rather, non-problem, of the relationship between legal theory and practice. ${ }^{31}$ For Wakin, real documents fueled the jurists' quest to

29 Jeanette Wakin, "Remembering Joseph Schacht (1902-1969)," Occasional Papers of the Islamic Legal Studies Program [at Harvard University] 4 (2003), $4-5$.

30 Schacht, review of Tyan, Notariat, 522. The desire to avoid legal dispute was also behind the notaries' development of a new genre of document in the fourth/tenth century, the iqrär(acknowledgment of debt), to replace the dhikr haqq, which was legally less watertight. All known adhkār huqqūq are written on papyrus, while to the best of my knowledge all known iqrārātare on paper and parchment, suggesting that the latter had indeed definitively replaced the former by around 940 .

31 Wakin, Function of Documents, 2 nn. 1-3, 25-26, 45-50, and passim 
produce ever more watertight formulations and, conversely, real notaries came to rely on the formulations in the shurut $t$ books; as she put it, "documents in judicial practice were appropriated from model documents, and these in turn were drawn from the world of practice." ${ }^{32}$ Documents also fed Wakin's sharp analysis of the structure of sales contracts, which is more than worthy of the corpus of philological scholarship on medieval semitic-language documents, though it preceded it by decades.

I find it all the more striking, then, that Wakin didn't edit any papyri herself. To the contrary, she described papyri as "inaccessible," "scattered ... all over the world," and "extremely difficult to read" and she seemed to find it entirely normal that "only a relatively small proportion has been published," or at least to be resigned to the situation..$^{33}$ Were the philologists who published papyrus and paper documents in the 1960s - Adolf Grohmann, Samuel Miklos Stern, Nabia Abbott - such exalted beings that even excellent Arabists didn't try to join them in their quest to fill the world with more editions? ${ }^{34}$

But when a larger proportion of papyri finally was published, they reinforced some of Wakin's conclusions. In 1993, Geoffrey Khan published a spate of new editions of documents on papyrus and paper. ${ }^{35}$ On Khan's view, the documents demonstrated the force of al-Tahawī's impact on notarial practice in Egypt: bills of sale from Fatimid-era Fusțāt read as though the notaries had adopted them from the pages of al-Tahāwīi, sometimes expanding them to render their formulations legally more secure. ${ }^{36}$ Khan's editions were followed in 1996 and 2006 by Michael Thung's corpus of loan documents, adhkār huqūq for

(I stopped hunting for references to papyri after fifty pages).

32 This and the previous quoted phrase are from Wakin's Encyclopaedia of Islam article s.v. "shart.."

33 Wakin, Function of Documents, 2.

34 Some papyrologists also played a role in perpetuating this myth; see Rustow, Lost Archive, 447-48 and 527 n. 102.

35 Geoffrey Khan, Bills, Letters, and Deeds: Arabic Papyri of the $7^{\text {th }_{-}}$ $11^{\text {th }}$ Centuries (Khalili Collections 1993); Khan, Arabic Legal and Administrative Documents.

36 Khan, Bills, Letters, Deeds, 175; cf. Khan, Arabic Legal and Administrative, 52-55. 
the second and third centuries and iqrārāt for the fourth. ${ }^{37}$ The jurists had deemed the dhikr haqq vulnerable to contestation; that the iqrār had replaced it was yet more demonstration of their impact on notarial practice.

Documents did not, then, occupy a different universe from the jurists' prescriptions, at least in Egypt in the middle period.

That doesn't mean we're out of the woods, however. Challenges remain. Christian Müller, for instance, has demonstrated that the corpus of nine hundred legal documents from Jerusalem in the 1390s evinces a wider variety of types and formulaic structures than one finds in the shurüt literature of the period..$^{38}$ It shouldn't be surprising that notarial practice is more unruly - and creative - than the handbooks let on, or can correct for. The same difficulty pervades administration, bureaucratic practice and fiscality: practice is more unruly than theory ${ }^{39}$ (In medieval Jewish law, too, the relationship between the shurüt books and the shur $\bar{t} t$ themselves is disconcertingly indirect, but here, part of the problem seems to be that the surviving shurūt manuals come from Iraq and the documents from Egypt.)

37 Michael H. Thung, "Written Obligations from the $2 \mathrm{nd} / 8$ th to the 4th/10th Century," Islamic Law and Society 3 (1996): 1-12; and Thung, Arabische juristische Urkunden aus der Papyrussammlung der Österreichischen Nationalbibliothek (Corpus Papyrorum Raineri 26) (Munich, 2006).

38 Christian Müller, Der Kadi und seine Zeugen. Cf. Müller, "Écrire pour établir la preuve orale en Islam: La pratique d'un tribunal à Jérusalem au XIVe siècle," in Les outils de la pensée. Étude historique et comparative des textes, eds. Akira Saito et Yusuke Nakamura (Paris : Maison des Sciences de l'Homme, 2010), 63-97, at paragraph 6. I'm not convinced that in the domain Müller is discussing, documents in legal proceedings, an "antagonisme entre théorie et pratique ... a dominé trop longtemps notre vision du droit musulman prémoderne," and I also don't think that's what Schacht means by "the contrast between theory and practice" in the passage Müller cites (Introduction to Islamic Law, 199). Schacht appears to be referring to the difference between what ordinary Muslims do and what they are supposed to be doing according to Islamic law (abstaining from pork and wine, to use Schacht's examples) - not to the difference between how courts functioned and how jurists wanted them to function. The "contrast between theory and practice" Schacht intends here is constitutive of all legal systems by definition: there wouldn't be laws against exceeding the speed limit were humans unwilling and cars unable to do so.

39 The aporia of S. M. Stern "Three Petitions of the Fāṭimid Period," Oriens 15 (1962): 172-209, is another instance of this. 
We should, then, neither lament the disjunction between long-form texts and documents nor pretend that it doesn't exist. Instead, we should attempt to explain it. ${ }^{40}$

\section{Procedural PSeudo-Knowledge}

I'm a social historian. I write history from the ground up. I believe that physical contexts, material objects and human relationships are indispensable to our understanding of the past. For historians like me, personnel, procedures and social power are an integral part of understanding how law and judicial systems functioned in real time.

But even the most anthropologically oriented social historians can delude themselves into thinking they have a clearer picture of how things worked than they really do. I've recently come to understand, thanks to a project I undertook with the historian and Jewish law scholar Eve Krakowski, that geniza specialists have unknowingly absorbed and purveyed what she calls "pseudo-knowledge" about how Jewish courts functioned in tenth to thirteenth-century Egypt and Syria. This is a variant of a phenomenon Mark Cohen has dubbed the "optical illusion" created by Goitein's Mediterranean Society - the illusion being that his five-volume work is coterminous with the contents of the Cairo Geniza. It isn't.

Goitein depicts the Jewish judicial system in deceptively concrete terms. Judges sit "on the bench." There are "chief judges" in Fusțāt and "puisne judges" outside Fusțâț (puisne is his translation of $n \bar{a} ' i b$ ). You can almost picture the black robes and powdery white wigs. He writes that judges "normally" doubled as notaries, suggesting that geniza evidence presents us with norms, not a congeries of potentially contradictory tidbits

40 A successful attempt to do this is Mark R. Cohen, Maimonides and the Merchants: Jewish Law and Society in the Medieval Islamic World (Philadelphia: University of Pennsylvania Press, 2017). Where Maimonides's code of Jewish law veers off the course set by the ge'onim, particularly in commercial law, Cohen musters geniza documents demonstrating that he was bringing Jewish law into line with what was the practice in his day. 
and semi-anonymous scribes. ${ }^{41}$ He paints a clear hierarchy of officials. He makes things seem more stable and real than they may have been. On closer inspection of the documents, some of those descriptions dissolve - not into total nothingness, but into skeletal outlines shot throuogh with large gaps.

With these cautions in mind from the Jewish court and notarial documents, I pose the following problems about the Islamic ones.

First: who wrote $q \bar{a} d \bar{l}$-court documents? For Tyan, Schacht, Wakin and Khan, notaries evolved from the class of professional witnesses. Tyan and Wakin cite Ibn Khaldūn's claim that in each city, notaries have shops where they both "function as witnesses and register (testimony) in writing." ${ }^{42}$ Wakin and Khan find ample corroboration for that claim in the documents, since many are written in the same hand as one of the witnesses' signatures, demonstrating that notaries served as witnesses, or vice-versa.

I am prepared to believe that a certified witness who hung around the courts could also learn to draw up documents. But we still don't know how such a transformation happened historically. Literacy was limited in preindustrial cultures, and the technicalities of writing had to be learned - not just imitating script, which is complex enough, but cooking ink, cutting reeds, and preparing or procuring writing supports. The layout and script of court documents are uniform enough to suggest they were learned in apprenticeship. The flexibility with which scribes handled formulary likewise suggests that they didn't slavishly follow models, that they were creative and knew what they were doing. Good scribes are like chefs: they don't mechanically reproduce recipes, but vary their output based on the occasion and the ingredients at their disposal. ${ }^{43}$ The script

41 S. D. Goitein, A Mediterranean Society: The Jewish Communities of the Arab World as Portrayed in the Documents of the Cairo Geniza, 6 vols. (Berkeley: University of California Press, 1967-93), 2:53, 70, 125.

42 Ibn Khaldūn, Muqaddima, 1:462, quoted in Tyan, Notariat, 39, and Wakin, Function of Documents, 9.

43 Marina Rustow, "The Diplomatics of Leadership: Administrative Documents in Hebrew Script from the Geniza," in Jews, Christians and Muslims in Medieval and Early Modern Times: A Festschrift in Honor of Mark R. Cohen, eds. 
styles of the legal documents are consistent (or consistently illegible, to echo Schacht's complaint), and also conspicuously different from other types of writing. In some Arabic-script legal documents from the geniza, $q \bar{a} d \bar{\imath} \mathrm{s}$ are also described as official witnesses, judges may well have served as notaries; there was a flexibility of roles and a continuum of expertise. ${ }^{44}$

But if notaries witnessed the very documents that they themselves drew up, didn't this vitiate the purpose of certifying the document for its authenticity? Christian Müller has offered a possible solution based on the Jerusalem legal documents: he argued that witnesses affixed their signature to a document not to secure its probative function, or even to assert that the transaction recorded there had occurred, but instead to signal that they would testify about the transaction in person before the judge. So, if you walked into a court with a signed document, you were, in effect, telling the judge that you had witnesses at your disposal who were willing to testify that the legal act recorded in the document had taken place. The judge didn't have to accept the document; he only had to call on the witnesses who had signed it. ${ }^{45}$ This solution is persuasive for the documents Müller discusses from the Haram al-Sharif, but it must be tested elsewhere. There is much else that we still don't understand about witnessing, including the role of professional witnesses - though for the early period, Mathieu Tillier's L'invention $d u$ cadi, to which I'll return below, has cut through the fog in part

Arnold Franklin, Roxani Margariti, Marina Rustow, and Uriel Simonsohn (Leiden: Brill, 2014), 306-51 (344).

44 T-S Misc. 29.24 (Khan, ALAD, doc. 23); T-S Misc. 29.8 (Khan, ALAD, doc. 41); T-S Ar. 40.126(edition in Șabīh 'Aodeh, "Eleventh Century Arabic Letters of Jewish Merchants from the Cairo Geniza" (Hebrew; PhD diss., Tel Aviv University, 1992), doc. 69; English translation in Goitein, Letters of Medieval Jewish Traders [Princeton, 1973], 270-71; see Khan, ALAD, 165 n. 6).

45 Christian Müller, "Écrire pour établir la preuve orale en Islam: La pratique d'un tribunal à Jérusalem au XIVe siècle," in Les outils de la pensée: étude historique et comparative des textes, eds. Akira Saito and Yusuke Nakamura (Paris: Maison des sciences de l'homme, 2010), 63-97; Müller, "The Power of the Pen: Cadis and Their Archives. From Writings to Registering Proof of a Previous Action Taken," 369. Schacht seems to be envisioning the same scenario in his review of Tyan, Notariat, 520: "the quality of ' $a d l$ is not in itself indispensable in the person who drafts legal documents, it is only convenient insofar as he may later be called upon to act as one of the witnesses." 
by ignoring the generalities of prescription, focusing instead on historically attested practices and distinguishing among the procedures of different regions and periods. ${ }^{46}$

Other details require equally careful parsing. Witnesses weren't always present either for the writing of a document they signed or the legal act it recorded. They might sign on different days, sometimes months apart. The chemical analysis of inks on rabbinical court documents from the geniza - a promising new area of study - suggests that witnesses signed in different inks, and if so, it would be reasonable to assume that they signed from the comfort of their own homes, but we don't know. ${ }^{47}$ If we don't actually know where witnesses were when they signed, how can we say we understand the judicial system? Because as scholars we get paid to sound knowledgeable, we may wish to avoid the distressing sensation of ignorance and focus instead on what's more abundantly documented. But this is a case in which we should lean into our ignorance: instead of avoidance, we need new questions, creative solutions and, above all, more editions of texts.

There are other mysteries of legal setting. At what point (and where) do we find courts that are brick-and-mortar institutions, or that they met in mosques, or that they were merely informal aggregations around the authority of the judges, who heard cases at home? Were pre-Ottoman Islamic courts really "not bound to a given physical space but to the judge's person"? 48 If not, how does this affect our ideas about court procedure, or about court archives? Annotations on documents demonstrate that courts kept archives, and (pace the influential argument

46 Mathieu Tillier, L'invention du cadi. La Justice des musulmans, des juifs et des chrétiens aux premiers siècles de l'Islam (Paris : Publications de la Sorbonne, 2017). On written proof, see 348-54.

47 See Zina Cohen, Judith Olszowy-Schlanger, Oliver Hahn and Ira Rabin, "Composition Analysis of Writing Materials in Geniza Fragments," in Jewish Manuscript Cultures: New Perspectives, ed. Irina Wandrey (Berlin: De Gruyter Open Books, 2017): 323-38.

48 Khan, ALAD, 7, 100; Delfina Serrano Ruano, "Qadis and Muftis: Judicial Authority and the Social Practice of Islamic Law," in Routledge Handbook of Islamic Law, eds. Khaled Abou El Fadl, Ahmad Atif Ahmad, and Said Fares Hassan (London: Routledge, 2019), 156-71, esp. 160. 
of Wael Hallaq), in many cases they long outlasted the judges; we also know that some mosques had both archives and other document repositories. ${ }^{49}$

There are other questions of acute concern to experts in Islamic law that simply don't appear in the documents, suggesting that they may have been less important in everyday legal proceedings. Documents are equivocal on scholastic differences. The notaries' goal was to make their deeds valid to judges of any persuasion. They therefore avoided using bits of formulary over which the legal schools differed, as a matter of legal precaution (ihtiyāt or taharruz), as al-Ṭahāwī put it. ${ }^{50}$ Nor can we assume a $q \bar{a} d \bar{\imath}$ 's affiliation from the outcome of a case: despite the reasonable expectation that $q \bar{a} d \bar{\imath} \mathrm{s}$ would apply "the fully developed legal doctrine of a specific law school (madhhab)," three of the Sunnī schools held that the appointment of a $q \bar{a} d \bar{l}$ who had attained the status of mujtahid was invalid if made on condition that he would adhere to the doctrines of a school. Only the early Hanafîs allowed such a stipulation (and only then if the madhhab in question was the $q \bar{a} d \bar{\imath}$ 's own). ${ }^{51}$

These rules seem to be a straightforward means of ensuring the independence of the judiciary from political power. But did they? Mathieu Tillier's work on mazālim in Abbasid Egypt paints a more complex picture..$^{52}$ Christian Müller, meanwhile, has cautioned that often judges rendered no decision at all, but

49 Wael B. Hallaq, "The quạd $\vec{\imath}$ s dīwān (sijill) before the Ottomans," Bulletin of the School of Oriental and African Studies 61 (1998): 415-36, with the argument contra in Rustow, Lost Archive, 67-73. There was a mosque repository for books and documents at the Umayyad mosque in Damascus; see D'Ottone Rambach, Hirschler and Vollandt, The Damascus Fragments.

50 Wakin, Function of Documents, 32; Khan, ALAD, 7, 100.

51 Muhammad Khalid Masud, Rudolph Peters and David S. Powers, "Qāọīs and Their Courts: An Historical Survey," in Dispensing Justice in Islam: Qadis and Their Judgments, ed. Muhammad Khalid Masud, Rudolph Peters and David Powers (Leiden: Brill, 2006), 1-44, esp. 14.

52 Mathieu Tillier, "The Mazalim in Historiography," in The Oxford Handbook of Islamic Law, eds. Anver M. Emon and Rumee Ahmed (Oxford: Oxford University Press, 2019); Tillier, "Qāộ̄is and the Political Use of the Mazāāim Jurisdiction under the 'Abbāsids," in Public Violence in Islamic Societies: Power, Discipline, and the Construction of the Public Sphere, 7th-18th Centuries CE, eds. Christian Lange and Maribel Fierro (Edinburgh: Edinburgh University Press, 2009), 42-66. 
rather presided over a process of arbitration,,$^{53}$ and where this is true, it would compound the difficulty of understanding the relationship between law and documents. Documents also hide legal reasoning and argumentation since, as Chibli Mallat has put it, they "register a fact which has either never been disputed, or one the dispute over which has now been settled." 54

The documents may likewise be hiding evidence of forum-shopping among the madhhabs. There is abundant evidence of it in other kinds of sources, so we might suspect that it was happening de facto. But even from Fatimid-era $q \bar{a} d \bar{l}$-court documents, it's not possible to discern whether all the judges were Ismā 'ìlī. The formulae continue general Egyptian notarial practice as consolidated after al-Ṭahāwī, as Khan notes; there is nothing Ismā $\overline{1} l \overline{1}$ about them, though Ismā $\overline{1} l \overline{1}$ judges and officials do appear in them. ${ }^{55}$ Since Fatimid caliphs and viziers granted investitures to Jewish and Christian judges, it's not far-fetched to imagine them granting investitures to Sunnī judges. But if this is the case, then the judicial system had multiple levels that still

53 Christian Müller, "Settling Litigation without Judgment: The Importance of a Hukm in Qâdî cases of Mamlûk Jerusalem," in Dispensing Justice in Islam: Qadis and their Judgements, eds. Muhammad Khalid Masud, Rudolph Peters and David Powers (Leiden: Brill, 2006), 47-70.

54 Chibli Mallat, "From Islamic to Middle Eastern Law: A Restatement of the Field (Part II)," The American Journal of Comparative Law 52 (2004): 209-86, esp. 249-50. Cf. Brinkley Messick, "The Judge and the Mufti," in The Ashgate Research Companion to Islamic Law, eds. Rudolph Peters and Peri Bearman (Ashgate, 2014), 82 .

55 See, e.g., the 'alāma of an anonymous judge, "allāh al- 'u[m]da," at the top left of a fifth/eleventh-century marriage contract, T-S Ar. 38.61 (Khan, ALAD, 34); the judge Abū 'Alī al-Ḥasan b. 'Alī b. Ḥassān in an iqrār from 534/1140, T-S 8J5.8 (Khan, ALAD, doc. 43; the name and kunya are ambiguous, since in this period even Jews could bear any of them); and the anonymous judge in a fifth/eleventhcentury court record, T-S Ar. 38.71 (Khan, doc. 59), lines 3 and 11-12, 14, 18. The situation is, however, clear when Fatimid-era documents identify judges as $q \bar{a} \bar{d} \bar{\imath} a l$ quḍāt, e.g., Abū al-Fath 'Abd al-Hākim b. Sa īd b. Mālik b. Sa'īd, in a marriage contract of 419-27/1028-36, T-S 18J1.10, line 5 (Khan, ALAD, doc. 32). A more ambiguous case is the judge mentioned in a lease document for a government property from 509/1115, T-S Misc. 29.24, recto, lines 6-7 (Khan, ALAD, doc. 23), Abū 1-Ḥasan Muḥammad b. Hibatallāh b. al-Ḥasan, who is described as a certified witness (shähid 'adl) and also as "head of the office of prosperous Friday and neighborhood mosques in Cairo al-Mu izziyya, may she be guarded, and Fustạtt, and of the office of intestate property (mawārith hashriyya), and of the auspicious granaries." Since he ran the mosques in the capital, it's probably safe to assume he was Ismā î̀li. 
need to be parsed. As much as the documents obscure about the judges, they reveal about the calm imperviousness of everyday notarial practice to the kinds of issues we might have expected, based on the legal writings, to bother people. Was notarial practice its own sphere, then? If so, what about those judges who doubled as notaries?

In sum, documents show that there are dimensions to law that we haven't adequately explored.

\section{Please go find yourself Some documents}

One could be forgiven for concluding that reconciling the documents with the writings of the jurists is too large a task for one person. I would suggest, in fact, that it's the job for a subfield. Let's found one.

Subfields solve the problem of a standing army, but an army still needs to define strategies when faced with complex problems - likewise researchers before recalcitrant evidence. We've tried our current division of labor, and we've had underwhelming results. I would suggest, then, that we train students to cross the divide between documents and long-form texts. As for how to tackle the problem of documents and judicial systems, rather than tackling it whole, let's break it into smaller, more conquerable pieces. Recent books have made an excellent start on this, and they've tended to break the problem up in one of two ways: by tracing the history of institutions over time, and by offering microhistories of a single system.

The institution-over-time approach drives Mathieu Tillier's magisterial L'invention du cadi. The book promises to trace the emergence of the office of $q \bar{a} d \bar{l}$ from among a wider array of legal arbiters in the Umayyad period. In fact, it does more: it tells a wider story of early Islamic judicial systems. The difference is important. French distinguishes rigorously, as Tillier notes in his introduction, between "legal" and "judicial," so there are "legal questions," questions juridiques, but "judicial systems," systèmes judiciaires, where English might use "legal" 
for both. ${ }^{56}$ The book is about the second entity.

One of the book's major interventions in Islamic legal history is how it frames its question. On Tillier's view, previous attempts to trace the history of Islamic law have either treated their subject in an institutional and social vacuum or else flattened regional differences. Instead, he takes a "horizontal," "polycentric" approach, examining the judicial systems run by pagarchs, governors, caliphs, and even rabbis and bishops. Rather than focusing on jurists, judges, or even the broader range of legal specialists, Tillier tries to reconstruct the many public institutions and officials that meted out justice, and then to ask how these eventually led to the establishment of judgeships. If you'll forgive the historical whiplash, Tillier's book does for Islamic legal institutions what Yuval Noah Harari's Sapiens does for the history of humankind: it offers a glimpse of the alternatives that died out or assimilated when the species $q \bar{a} d \bar{\imath}$ pulled away from the postdiluvian scrummage.

Tillier's book is far so rich with source material and rife with careful interpretation that I can't possibly do it justice here. (Among other things, I am particularly struck by Tillier's intellectual honesty in presenting hypotheses and counter-hypotheses and allowing his reader to choose among them.) In this context, I want to point to the extraordinary first chapter, in which Tillier sifts through the published papyri - still a small fraction of the extant papyri, though more than Wakin had at her disposal, and they're now searchable in a database - to identify in administrative and legal documents the range of options available to those seeking justice. There are petitions and other appeals for arbitration to pagarchs, amīrs, sub-governors and governors (including the perennial star of papyrology Qurra b. Sharīk, an Umayyad governor of Egypt); and there are rescripts and letters in response to appeals. Thirty-five of the documents in Tillier's corpus are from Egypt and three from Palestine; even within Egypt alone, there are levels of authority in the game, local, intermediate and regional. He concludes that there were no $q \bar{a} d \bar{\imath} \mathrm{s}$ until the Abbasid period. Even then, Sapiens-like, they still

56 Tillier, L'invention du cadi, 19. 
weren't the only option available to those seeking justice. And then, having combed through the documents, Tillier launches on four chapters on the long-form sources, well-positioned to discern where they're retrojecting $q \bar{a} d \bar{l} \overline{\mathrm{s}}$ onto a period before they existed.

Tillier's book demonstrates the wisdom of the rule that if you're having trouble solving a problem, reframe it. Tracing the history of a single official such as the $q \bar{a} d \bar{\imath}$ might have yielded sterile or tautological results. Widening the field of inquiry to include other officials who dispensed justice yields a different picture not just of a single office, nor just of Islamic law, but of something much broader: justice.

A second way to break the problem into bite-sized pieces is to write microhistory. This is a classic technique among social historians, and it should have great appeal to legal historians, too..$^{57}$ The microhistorical approach revolutionized historical writing in the 1970s by narrowing its scope and delving into tiny details of the everyday world. By building up texture, microhistories bring into the open the assumptions, unspoken knowledge and unconscious habits of thought that would be unrecoverable with more traditional methods and sources. Microhistory trucks in the humble and ordinary, and in elites only insofar as they encounter the humble; it trucks not the exception, but in a mass of evidence of the unremarkable. Unlike a mere case-study, a microhistory allows conclusions to emerge from patiently accumulated detail, not via an illustrative or part-for-whole logic.

Some recent works of legal history could be described as microhistories. Among them is Eve Krakowski's book on marriage patterns among Jewish women in Fusțāt, Coming of Age in Medieval Egypt, a title that echoes Margaret Mead's ethnographic classicComing of Age in Samoa; both are about adolescent girls, and recover an entire culture through them. ${ }^{58}$ Krakowski's corpus

57 The classic of the genre is Carlo Ginzburg, The Cheese and the Worms: The Cosmos of a Sixteenth-Century Miller, trans. John and Anne C. Tedeschi (Baltimore: The Johns Hopkins University Press, 1980); see also Ginzburg, "Microhistory: Two or Three Things That I Know about It," Critical Inquiry 20 (1993): 10-35.

58 Eve Krakowski, Coming of Age in Medieval Egypt: Female Adoles- 
of geniza sources is exceptionally unforgiving. They include betrothal, engagement and marriage contracts in Aramaic, Judaeo-Arabic and Hebrew, which are mostly formulary, while the fungible information they contain is drily demographic. But through the patient aggregation of detail, Krakowski arrives at some startling conclusions. The first is the divorce rate among Jews in Fatimid and Ayyubid Fusțāt — which was as high as Yossef Rapoport found among Muslims in the Mamluk period..$^{59}$ The second is that relatively few children grew up in a single household with a stable set of adults, a significant finding given that not all the adults married within their own religion or school, and religious and scholastic traditions were learned mimetically at home, even among those who had access to books, which means that children had access to many schools of religious practice. The third is that the culture of patronage and reciprocity that Roy Mottahedeh documented in his much beloved Loyalty and Leadership and an Early Islamic Society was highly gendered. In fact, patronage and institutionalized reciprocity were resources for men, but they worked for women only insofar as those women had male patrons who were kin or, barring that, communal and state officials, which is so impersonal as almost not to count as patronage at all. ${ }^{60}$

Most intriguing, however, is the central claim of Krakowski's book. The social historical data she pulls from those marriage contracts reveal that Jewish marriage habits resembled those of medieval Muslims more than of late antique Jews. This isn't the surprising bit; what is is that while Jewish marriage wasn't socially distinctive, Jewish marriage contracts nonetheless carefully followed late antique rabbinic technical legal norms, and made a point of doing so. Jews were committed to contracting their marriages according to Jewish law even as they married like Muslims, and not just as a way of reinforcing

cence, Jewish Law, and Ordinary Culture (Princeton: Princeton University Press, 2018).

59 Yossef Rapoport, Marriage, Money and Divorce in Medieval Islamic Society (Cambridge: Cambridge University Press, 2005).

60 Oded Zinger's book-in-progress draws analogous conclusions for female litigants in the Jewish courts. 
Jewish distinctiveness; Jews also had a distinctively Islamicate (the suffix matters) idea of what it meant to have a legal tradition.

The book is an organic outgrowth and a departure from previous legal studies on the geniza, which tended to focus narrowly on the evolution of document types, or else on male social networks and communal administration. Krakowski's book reconstructs the institutions behind the documents and the user-end of the judicial system. It's microhistorical inasmuch as it begins from girls' age and status (legal and economic) at first marriage and ends with bold conclusions about a much bigger question: what it meant for Jews, Christians and Muslims in a remade Middle East to nurture legal (in the sense of juridique) institutions and judicial (in the sense of judiciaire) systems that they recognized as such.

Christian Müller's impressive study of the al-Aqșā documents has also been called "microhistory." ${ }^{11}$ Though his work comes from a different angle from Krakowski's, it shares her method of pulling history from legal documents not by discarding the fixed formulae (an act of deboning, as Tamer el-Leithy once memorably put it), but by fearlessly devouring them. No detail escapes Müller's curiosity, from the smallest (and most perplexing) marginal annotation to the layout and format of the page. No document type escapes his notice, either, from lists and inventories to otherwise unattested types of testimony and deed.

Like Tillier's book, Müller's is too complex to summarize in two paragraphs; given the state of my German (and the forbidding style of his), I'm sure I've overlooked key points. The book shows how the patient accumulation of documentary evidence can yield a whole that is greater than the sum of its parts - in his case, two wholes. The first is the shape of the Haram corpus itself, which Müller reinterprets not as the archive of a $q \bar{a} d \bar{\imath}$ (as its cataloguer, Donald Little, had it), but as a massive dossier of evidence assembled to defend said $q \bar{a} d \bar{\imath}$ against allegations of corruption. ${ }^{62}$ The second whole is a provincial

61 Müller, Der Kadi und seine Zeugen; Konrad Hirschler, review in Islamic Law and Society 25 (2018): 157-61, esp. 157, 159.

62 Christian Müller, "The Haram al-Sharīf Collection of Arabic Legal Documents in Jerusalem: A Mamlūk Court Archive?” al-Qanțara 32 (2011): 435-59. 
Mamluk legal culture with idiosyncratic (or at least unattested) norms of document production, its own systems of document storage and retrieval, and a complex relationship to the state on the one hand and the doctrines of the jurists on the other. Like Tillier - and also like Kristen Stilt's study of the muhtasib in Mamluk Cairo ${ }^{63}$ - Müller has situated his study at the intersection of the state and judicial institutions, a vantage point from which generalizations about Islamic law, even Islamic law in a given time and place, are bound to seem hollow.

Just how hollow we won't know until we have more documents to study. Documents complicate the picture; an abundance of documents complicates it exponentially. Thirty years after Khan's landmark corpora, many hundreds or thousands of unpublished legal documents still await their debut onto the stage of scholarship. From personal experience, I can assure you that with hard work, good bookkeeping, regular reading sessions and reliable comrades, even someone with no prior training in Arabic paleography can learn to make sense of legal documents - all the more so scholars who know how to read the long-form Islamic legal works. The road to documentary glory is paved in the usual way of manuscript journeys: find the texts, decipher them (the more of them the better, since illegible segments and lacunae in one document get filled by others), understand them, contextualize them and, in the spirit of Tillier and Müller, interpret them both closely and with an eye on larger wholes. There are discoveries to be made; I urge you to try.

63 Kristen Stilt, Islamic Law in Action: Authority, Discretion, and Everyday Experiences in Mamluk Egypt (Oxford: Oxford University Press, 2011). 